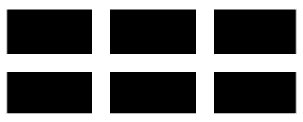

THE WILLIAM DAVIDSON INSTITUTE AT THE UNIVERSITY OF MICHIGAN BUSINESS SCHOOL

\title{
Credibility and Adjustment: Gold Standards Versus Currency Boards
}

By: Jean Baptiste Desquilbet and Nikolay Nenovsky

William Davidson Institute Working Paper Number 692 May 2004 


\title{
Credibility and adjustment: gold standards versus currency boards
}

\author{
Jean Baptiste Desquilbet \\ LEO, Université d'Orléans, France \\ jean-baptiste.desquilbet@,univ-orleans.fr \\ and \\ Nikolay Nenovsky \\ University of National and World Economy, Sofia, Bulgaria, \\ LEO, Université d'Orléans, France, \\ Bulgarian National Bank \\ nenovsky.n@,bnbank.org
}

11 May 2004

Summary: It is often maintained that currency boards (CBs) and gold standards (GSs) are alike in that they are stringent monetary rules, the two basic features of which are high credibility of monetary authorities and the existence of automatic adjustment (non discretionary) mechanism. This article includes a comparative analysis of these two types of regimes both from the perspective of the sources and mechanisms of generating confidence and credibility, and the elements of operation of the automatic adjustment mechanism. Confidence under the GS is endogenously driven, whereas it is exogenously determined under the CB. CB is a much more asymmetric regime than GS (the adjustment is much to the detriment of peripheral countries) although asymmetry is a typical feature of any monetary regime. The lack of credibility is typical for peripheral countries and cannot be overcome completely even by "hard" monetary regimes.

JEL classification: E4 (E42)

Key words: monetary regime, gold standards, and currency boards

*We have benefited from discussions with participants in a LEO Research Seminar (16 march 2004) and University of Amiens Research Conference (18 March 2004), and especially with Philippe Saucier, Georges Galais-Hamonno, Jean Paul Pollin, Anton Mendonca, Jerome De Boyer des Roches, Edwin de Heron and Nicolas Moumni. Remaining errors are ours. 
"Heraclitus somewhere says that all things are in process and nothing stays still, and likening existing things to the stream of a river he says that you would not step twice into the same river."

Plato, Cratylus 402a

\section{Introduction}

During the $20^{\text {th }}$ century and particularly its second half monetary regimes became gradually standardised and unified around two basic features - national monetary monopoly and discretionary monetary policy. Monetary policy became an active instrument for steering the internal economic goals of national countries. However, at the end of $20^{\text {th }}$ and beginning of $21^{\text {st }}$ century the pendulum reversed its swing and we have been witnessing a greater institutional diversity, as well as a kind of a return to some forms of monetary regimes typical of $18^{\text {th }}$ and $19^{\text {th }}$ century ${ }^{1}$. Currency boards (CB), monetary unions, dollarization, as well as the formation of global monetary areas are evidence in support of this. Often started as a purely short-term stabilisation measure or for specific political reasons, these forms gradually evolve into longterm institutional conditions for development and stability.

Whenever CBs are discussed, they are almost inevitably compared to the gold standard (GS) as a very similar type of rule ${ }^{2}$. The similarities are usually limited to assertions such as: (i) the two monetary regimes are characterised by a higher level of credibility and confidence; they are a type of "monetary constitutions"; (ii) the two regimes are good tools for integrating national economies into the world economy; (iii) there is an automated mechanism, which links money demand and money supply to balance of payments and leads to quick elimination of imbalances. In broad terms, automatism means that one way or another there are cause-andeffect chains and two-way interaction whereby without the discretion of a central monetary authority (or with it, while, however, observing "the rules of the game" ${ }^{3}$ ) the balance is adjusted after a shock; (iv) both types of monetary regimes bring external limitation to the fore much to the detriment of domestic economic policy; (v) both types of regimes are relatively rigid

\footnotetext{
${ }^{1}$ See the evolution of monetary regimes described by Bordo $(2002,2003)$

${ }^{2}$ For example at the end of their editor's introduction Eichengreen and Flandreau (1997), without going into details, mentioned the analogy of the gold standard with the currency boards. The same is done more recently by Kydland and Wynne (2002).
} 
(discretion is minimised) and restrictive (due to the restrictions faced by money supply and public finances). It is often argued that this not only makes them strongly susceptible to crisis, but also turns them into an obstacle for economic growth; (v) often, the two regimes are considered as stabilising measures after a period of financial crisis and hyperinflation (for instance: the stabilisation carried out by Poincare in 1926-1928, the introduction of the Tchervonets in Bolshevik Russia in 1924, the CB in Argentina in 1991, CB in Bulgaria in 1996/1997, etc.).

This article is not so much interested in comparing the efficiency of monetary regimes from the broad perspective of their appropriateness for the economic growth and development ${ }^{4}$. Without denying the link with growth and economic development, we rather focus on two other often-stressed features of these regimes, namely, the generation of confidence and credibility and the functioning of so-called automatic mechanism. The comparative analysis along these two lines provides elements for reflection as to what extent GSs and CBs restore and maintain the stability after a crisis, or provoke a crisis themselves.

From the standpoint of stability the dilemma of the two types of regimes is similar and could be brought to the following: how to combine external convertibility (the fixed exchange rate of the national currency, or balance of payments stability) with internal convertibility (the fixed exchange rate of banknotes versus deposits, or banking system stability (in the case of fractional banking system) $)^{5}$ ? The dilemma of the two convertibilities could be resolved in two ways (they complement each other): (i) by means of credibility and confidence in the monetary regime (often associated in the economic literature with "confidence and credibility effect") and

\footnotetext{
${ }^{3}$ Heilperin (1939) defines the adjustment mechanism with "the rules of the game" as induced re-equilibrium opposing it to automatic re-equilibrium (without requiring to "the rules of the game").

${ }^{4}$ Although according to Bernholz $(2001,2003)$ and Yeager $(2002)$ the $20^{\text {th }}$ century, which is the century of discretionary Central banks, is clearly the period witnessing the greatest number of monetary cataclysms and hyperinflation.

${ }^{5}$ This wording is limited to the most popular form of gold standard - fractional gold standard, where only part of money supply is covered by gold and the gold standard is combined with a money supply monopoly (i.e. gold standard with a Central bank). Further below the various forms of gold standard will be discussed. The proponents of the Austrian School believe that the pure standard "neither requires nor allows the state to control money supply" (Garisson, 1985). See also Della Paolera and Taylor (2001).
} 
(ii) by means of the operation of a certain mechanism or process, which could quickly restore the economy after a shock (often referred to in the economic literature as "discipline effect") ${ }^{6}$.

In spite of the numerous assertions for similarity between CBs and GS (see for instance Bernholz, 2003, Eichengreen and Flandreau (1997)), as far as we know, only Lewis (2002) has made an attempt at a more detailed comparison. In order to make up partially for this gap in economic literature we intend to step-by-step: (i) advance a definition of the two types of regimes taking into account the great diversity existing (part 2); (ii) look into the mechanisms (or sources) of generating confidence and credibility in money under the two types of regimes (part $3)$. Here, we are interested in how the credibility under the two types of regimes is generated (i.e., how and to what extent do CBs instil confidence in their efficient operation)? and (iii) to what extent is there a process of automatic self-equilibrium and what are its specific features under the two types of regimes (part 4). In other words, in part 4 we raise the question of whether there is any automatic mechanism often associated with the discipline effect of monetary rules. We also focus on to what extent the burdens of counterbalancing are symmetrically shared by the parties involved in the monetary regime.

\section{Definitions}

Seen through the eyes of modern economists, both GS and CB are easy to define and are viewed as a whole as monolithic regimes, i.e., without any material difference of forms. However, when we become familiar with even a small part of the historical economic literature and monetary history, it becomes evident that the above assumption does not at all meet the truth $^{7}$.

On first reading the immediate impression of the modern reader of the history of gold standard (especially the economic literature from end $19^{\text {th }}$ and the beginning of $20^{\text {th }}$ century) and currency boards, is the existence of a vast evolution and diversity within each of the two types of monetary regimes. The question that arises is: are these not different types of regimes and why

\footnotetext{
${ }^{6}$ Regarding this division see Combes and Veyrune (2003). De Grauwe (1996) in his study of GS operation reduces the issue of credibility to the existence of: (i) a national problem - the existence of automatic mechanism, (ii) and an international problem - the asymmetry between countries (or the problem of n-1 currency).

${ }^{7}$ One more proof in support of the fact that a huge volume of information is lost with time and that in the real life "history in general does not teach anything".
} 
are they included under a common category, and where is the dividing line? To overcome this difficulty partially at least, we will outline the possibilities for typology of the two types of regimes, even at the risk of losing certain information.

In the very beginning. Monetary regime $e^{8}$ in general will imply a system of formal rules and mechanisms for their enforcement, which determine to e certain extent the dynamics of money demand and supply, and in general the monetary behaviour of economic agents. Monetary system is a broader concept. In addition to monetary regime it also includes a number of informal rules and mechanisms (e.g. such as monetary substitution). The latter are manifested to a different degree depending on the period and country, but they always exist in some degree or another ${ }^{9}$. Or, if we put it in a different way, monetary practices can never be completely formalised $^{10}$.

As already mentioned, it would be a gross mistake to consider the gold standard as a monolithic type. We could, in fact, speak of different kinds of gold standards related with its evolution or its implementation in different countries and regions. There is a great institutional diversity; it is sufficient to look through a small part of the voluminous literature on gold standard published in the 20-ies and 30-ies of the last century (Mises, 1912; Laughlin, 1931; Nogaro, 1924; Aftalion 1927, 1936; Rueff 1927; Rist, 1938 etc.) ${ }^{11}$.

GS could be classified in a different way ${ }^{12}$; however, two institutional distinctions are of particular importance: (i) whether GS is under a private money arrangement or central bank arrangement, and (ii) whether GS is full or fractional. If we limit our institutional analysis within the monopolistic supply of money, i.e. if we ignore the arrangement of private gold money, then we could use (by way of combination) the classical definitions of Meade (1951) and Niehans

\footnotetext{
${ }^{8}$ The monetary regime concept is rarely defined although it is often used (Aftalion, 1938, Officer, 1996, Bordo, 2002). Things are different in political science and international relations (see Heilperin, 1939, De Cecco, 1974, Gilpin, 2001, Kebabdjian, 1999, Higgs, 1997)). An attempt at a new definition of monetary regimes, as well as a possible approach for explaining their change is made by Nenovsky and Rizopoulos (2003). Monetary regime is part of the monetary order (or monetary system), which also covers informal monetary practices. The natural monetary order is a competitive monetary order; it has to be an open complex process of continuous adaptation of money producers vis-à-vis the needs of money consumers. For more recent definitions on monetary regimes see Bernholz (2003).

${ }^{9}$ Even at the time of state socialism there existed a number of informal practices.

${ }^{10}$ See the description of various practices by Blanc (2000)

${ }^{11}$ For obvious reasons this literature overlapped in general with the theory of money as a whole.

${ }^{12}$ What is said about GS further below also applies to the silver standard, as well as to any commodity standard in principle.
} 
$(1978)^{13}$. This allows us to reduce the variety of gold standards to a single type of monetary regime.

Meade claims that GS is based on four major rules. First rule: each country fixes legally its national currency at the value of gold (convertibility principle). Here, depending on evolution, three mechanisms are observable: (i) gold-specie standard whereby gold is directly in circulation (in the form of bullion) and money supply is in effect fully backed up with gold; this standard could be referred to as pure gold standard; (ii) gold-fractional standard (gold-bullion standard); in this case, gold is not directly in internal circulation, but only among countries, while money supply is partially backed up with gold; (iii) gold-exchange standard, whereby national money is fixed to other national currencies, which are themselves functioning under the previous two regimes ${ }^{14}$. While under the first two types gold appears within a country, under the goldexchange regime it circulates only among national central banks.

Second rule. Under a pure GS there is a free minting of gold (anybody could receive a gold coin against gold brought by them to the Mint) as well as a free export and import of gold (which is the result of gold point arbitrage) ${ }^{15}$. In the case of more recent historical periods (when the balance of payments doesn't coincide with trade balance), this rule could be extended to requirement of free capital movements between the countries.

Third rule: each country should have in place adequate institutional and organisational structure, which would make money supply movement "more or less automatic", i.e. bind it to the movement of gold. The degree of such automation (with other factors coexisting) depends on whether the coverage is full or partial. With a partial coverage it is essential to observe the "rules of the game", which includes a type of interest rate discretion that allows a free movement of gold. This is an additional link to the mechanism of adjustment necessitated by the development of the banknotes and fiduciary form of money (Knafo, 2003). As mentioned, in the presence of the "rules of the games" within the adjustment mechanism we could speak of induced (Heilperin, 1939) instead of automatic adjustment.

\footnotetext{
${ }^{13}$ See also classification of gold standards in Heilperin (1939), Eichengreen and Flandreau (1997), McKinnon (1993), Bordo (2002) and Bernholz (1993)

${ }^{14}$ According to Laughlin (1931) and Nogaro (1924) this variety emerged with the monetary regimes in India at the end of $19^{\text {th }}$ century when silver rupies were backed up by British sterling pounds (which are themselves backed up by gold). Later on, such a system was implemented in Argentina and Austro-Hungary.

${ }^{15}$ Before free minting of gold coins came to exist (commencing with the French revolution onwards) there was a state monopoly in metal coins minting after the metal was bought out from the public (Nogaro, 1924).
} 
The coverage, which is fixed by law, could be of several types (three according to Meade, p. 182) depending on whether the national currency is fully or partially backed up with gold, in terms of whether the two variables are taken as stock or flow. The three configurations of coverage could be represented in a simplified way as follows: (if $\mathrm{G}$ stands for gold and $\mathrm{M}$ for money supply): (i) if $\mathrm{G}=\mathrm{M}$ and $\Delta G=\Delta M$ we would have 100 percentage money principles, (ii) if $\mathrm{G}<\mathrm{M}$ and $\Delta \mathrm{G}=\Delta \mathrm{M}$ we would have fiduciary issue principle, and when (iii) $\mathrm{G}<\mathrm{M}$ and $\Delta \mathrm{G}<$ $\Delta \mathrm{M}$ we would have percentage-reserve principle. The last form is the most common in history.

Meade refers to the above three rules as "rules of the need for external adjustment of the gold regime". He goes further and adds a fourth (national) rule, which requires extremely flexible national wages (and all prices in general).

Some other institutional specific features of GS should also be mentioned.

Firstly, the gold standard emerges as an informal private practice, a spontaneous monetary order, which stems from the very nature of money as a means of exchange. At a later stage, having proved efficient, this monetary practice became formalised and was reflected in the emergence of the gold monetary regime as a type of monetary constitution (Poole, 2003). In this respect, we could draw some parallels with the later legalization of informally appeared property rights (for example, De Soto, 2001).

Secondly, it should be noted that GS (or the silver standard, which is similar in this respect) is an international, global standard (or at least require cooperation between the countries) ${ }^{16}$. Depending on the time periods a great number of the major industrial countries and also peripheral countries functioned under such a regime. An illustration of that is the period of classical GS (1870-1914).

Thirdly, despite the fact that the GS regime became widespread, it operated on a very asymmetric basis, at all times, and especially after 1914, depending on whether adjustment was required in a core or a peripheral country (Triffin, 1968).

Fourthly, under that regime monetary policy was not part of the domestic economic policy, or at least was brought to certain automatism. The only obligation of the central bank was to maintain the convertibility and "observe the rules of the game" (by supporting the automatic 
mechanism via interest rate changes, Lelart, 1977, Plessis, 1998) ${ }^{17}$. For example in case of trade deficit, the losses of gold have to be followed by interest rate raise, which tend to reduce the portion of money not backed by gold (but by domestic securities) and/or to attract capital flows. Theoretically the rules of the game could work only for the core countries (De Cecco, 1974), but historically they were very often violated even at the core (Bloomfield, 1959). Bloomfield found "that there is no clear-cut evidence that the any central bank ever lowered its discount rate following gold inflows from abroad because of an explicit desire to play, or even because of awareness of, the "rules of the game" (1959, pp. 23-24). Furthermore, empirically Bloomfield proved that " in the case of every central bank the year-to- year changes in the international and domestic assets were more often in the opposite direction (60\% of the time) than in the same direction (34\% of the time), (1959, pp. 48-50). The same was found by Nurske (1944) and Simmons (1996) for the brief interwar return to gold standard. As a whole McKinnon (1993, p. 10) summarised "the popular textbook view of the classical gold standard as an automatic, selfequilibrating balance-of-payments adjustment mechanism is correct if one narrowly interprets it... we understand that the classical system was managed".

The second type of monetary regime we take interest in, the Currency Boards, is also characterised by a great institutional diversity (Schuler, 1992; Camillieri Gilson, 2002; Hanke, 2003). Obviously, that diversity is conditioned by historical reality. CBs emerge in various historical periods - in the colonial and postcolonial periods, or in post-socialism, with the emergence of new national state or at least partial national independency. The great number of institutional forms gives rise to a number of difficulties in defining the key features of CBs, as well as make them open to numerous disputes (Hanke, 2003). Anyway, if we try to ignore the details, we could reduce the $\mathrm{CB}$ features to the following:

First, an exchange rate legally fixed to a stable foreign currency of definite reputation for preserving the purchasing power ${ }^{18}$. Monetary authorities are obliged to exchange the national

\footnotetext{
${ }^{16}$ See Frieden (1992), Eichengreen (1997) and Knafo (2003) for the dynamic explanation of the internationality of the gold standard.

${ }^{17} \mathrm{Or}$, if we use modern terminology, we could say that within the function of the central bank reaction there were no (with few exceptions) domestic economic variables (see Bordo, 2003).

${ }^{18}$ Some authors claim that the fixed exchange rate is not among the basic features of a CB. They talk of a CB in the case of a floating exchange rate (Singapore). In Hong Kong, for instance, the exchange rate is not fixed by law, but by market arbitrage (Tsang, 1999).
} 
currency at that exchange rate (convertibility principle). In some configurations the reserve currency circulates as legal tender along with the national currency (the case with Argentina).

Second, a legally prescribed all time coverage (full or partial) of the base money with highly liquid foreign reserves, which are a $\mathrm{CB}$ asset ${ }^{19}$. As in modern economies money stock exceeds by much the base money, because of the development of bank money (unlike $19^{\text {th }}$ century for instance), this regime is more similar to the fractional form of the gold standard.

Third, the absence (or very insignificant presence) of money sterilisation (substitution of the reserve currency sources) ${ }^{20}$ and lender of last resort function. Interest rates are not employed as an instrument by the central bank, which is a basic feature of discretionary central banks. The crucial role for liquidity management is designed to the flexibility of the money market interest rate $^{21}$.

Fourth, liberalisation of the capital movement and price flexibility (including interest rate and salaries). This would also require the existence of a proper institutional framework (especially property rights) for the key economic players.

Five, in order to facilitate automatic adjustment (which link the balance of payments with the monetary supply), budgetary policy discipline is needed. The restoration of equilibrium of public finance could be considered as an integral part of "the rules of the game" in the case of CBs.

The above five conditions allow the emergence of "automatic" binding of the balance of payments dynamics with the reserve currency, and subsequently, by means of a number of

\footnotetext{
${ }^{19}$ The majority of modern CBs maintain foreign reserves in excess of monetary base.

${ }^{20}$ Steve Hanke empirically found out the existence of sterilisation in all modern CBs, which made him claim that they break the rule of lack of sterilisation, e.g. they are not orthodox (where sterilisation is zero). In spite of the difficulties in defining CB pure forms, Hanke (2003) attempts at defining such an archetype, the benchmark of an orthodox CB, against which variations could be measured. Thus, it becomes possible to decide to what extent the variations from this institutional benchmark account for the success or failures of CBs (taking into account, of course, the overall economic environment). It is again Hanke's belief that orthodox CBs are the ones, which possess, in addition to the fixed exchange rate, a few other features, in particular: (i) they do not hold domestic assets in their balance sheet, (ii) they hold on the liability side of their balance sheet only banknotes and coins, (iii) they assume full convertibility, (iv) do not have lender-of-last resort function, (v) do not regulate commercial banks, (vi) can not finance the government, and (vii) the foreign reserve coverage is $100-115 \%$. Based on this model of an orthodox CB all contemporary forms of CBs are unorthodox (Nenovsky and Hristov, 2002), and if CBs from the colonial system (which are much closer to orthodoxy) are referred to as first generation CBs, then modern CBs that possess a number of discretionary elements could be defined as a second generation CBs.

${ }^{21}$ See for more details Chobanov and Nenovsky (2004). In the respects of the role of interest rate for adjustment mechanism, the Currency boards are even more static and non-discretionary regime that the classical gold standard (at the core countries).
} 
interlinks, with money supply. Thus, the reliance is on a decentralised and "a-personal" adjustment of economy.

Some other specific features of CBs. First, the review of historical periods shows that CB is a primary domestic monetary arrangement and has been most often applied by single countries, usually less-developed ${ }^{22}$, of small or medium scale. These are countries, which completely fall under the "peripheral" category. Second, CBs in general emerge in specific transitional periods, such as: (i) during the transition from colonial system to national discretionary bank and monetary independence (colonial system) and (ii) after a period of financial crisis, which is itself caused by the monetary discretion of a central bank (Latin America and Eastern Europe). Third, unlike the gold standard, CBs are a totally constructed monetary regime; they do not emerge as a result of the spontaneous evolution of money. They are rather the result of the struggle and cooperation of certain groups of economic actors, usually domestic actors versus foreign ones (Nenovsky and Rizopoulos, 2003, 2004; Hanke, 2002, Blanc, 2003).

Building on the above definitions and notes we continue with analysis of confidence and credibility, which are often pointed out as a common feature of the gold standards and currency boards (the so called "credibility effect" of monetary rule).

\section{How are confidence and credibility generated?}

It is known that the efficiency of each monetary regime and central bank is judged by the extent to which it fosters confidence in money. It is exactly this confidence that is the key advantage recognised not only by the proponents of monetary constitutions (such as GS and $\mathrm{CB})^{23}$.

Confidence and credibility can be approached in a different way. We are not going to make a synopsis of the economic literature (see for instance Walsh, 1998, Carré and Le Heron, 2004); we will rather attempt to simplify things by capturing some major features of confidence and credibility of the two monetary regimes derived from practice.

\footnotetext{
${ }^{22}$ The level of Hong Kong life standard was raised after the CB introduction.

${ }^{23}$ It is not by chance that the CB in Lithuania was introduced by law, the so-called Law on the credibility of litas (see Blanc and Ponsot, 2003).
} 
To begin with, we have to make a distinction between the concept of confidence and the concept of credibility. While credibility is a feature of monetary authorities (of monetary regime, monetary system, and its long-term predictability), the confidence in a monetary regime is rather the attitude of economic players towards the monetary authorities and the monetary regime. Both credibility and confidence are subjective categories, related to a promise given (Ho, 2001). In the case of money, it is a promise for relative stability of the purchasing power of a national currency. While credibility relates to someone making a promise, confidence is related to the person who takes that promise. Both GS and CB are arrangements, which depend primarily and asymmetrically (while not always) on the person that has been given the promise. Thus human behaviour is an immediate source of a possible crisis. The discrepancy between the formal (or declared) rules of a monetary regime and practice (compliance with rules) is the basis for a change of actors' expectations, i.e. of their confidence.

The economic literature, which is almost entirely focused on the monopoly central bank, stresses credibility mainly - the way it is generated, the ways it relates to discretion and rules ${ }^{24}$, the best institutional form of monetary regime to maximise this credibility, etc. (Cowen et al., 2000). We are more interested in the confidence in GS and CBs, because we believe that it is essential for its stability. With a view to simplify things, we concentrate on the immediate sources of generating confidence in monetary regimes by looking into the practice of these two types of monetary regimes ${ }^{25}$.

\footnotetext{
${ }^{24}$ The discussion "rules - discretion" is relevant only within the framework of a monopolistic central bank; with the existence of private money this discussion becomes pointless.

${ }^{25}$ Carlson and Valev $(2001,2004)$ study the credibility of the CBA in Bulgaria using survey data. They insist on the differences in confidence due to individual socio-political characteristics, but they do not identify sources of confidence. See also the study on CB credibility in Bulgaria down by Ganev (2004).
} 


\section{Convertibility}

Most of the authors, who study the GS regime, point out that the major source of confidence is the full convertibility principle $^{26}$ : (i) the possibility to unrestrictedly mint currency, that is, to take gold to a mint and have a gold coin in return, or (ii) in the case of gold bullion standard, the possibility to claim and convert the national currency at a legally fixed exchange rate to the gold (see for example Laughlin, 1931, vol. II, p.16). While criticising Ricardo, who, as he believes, does not understand the meaning of convertibility ${ }^{27}$, Rist (1938, p. 203) says: "In short, the [gold] convertibility of banknotes is not just a 'trick' aimed at limiting their volume; the convertibility of a banknote attaches to it legal and economic characteristics, which are denied to fiat money, and which are not conditional on the amount of this money"28. Examples are numerous. For instance, it is not by chance that in public and professional discussions prior to the financial stabilisation of the franc in 1926-1928 (under Poincaré's Government) convertibility was stressed as a key element of the reform (Mouré, 1998). Another example Laughlin (1931) points out that the lack of courage in the Indian authorities (in the beginning of the $20^{\text {th }}$ century) to introduce a direct convertibility of the silver Rupees to the British gold currency (irrespective of the rupee coverage), undermines confidence and raises doubts of manipulation.

Within the convertibility principle we can establish two anchors of confidence: (i) the existence of a previously fixed exchange rate (to gold) and (ii) the coverage of money (we should have in mind that money stock used to be much closer to the currency in circulation than it is today, although even in those times currency substitutions rapidly emerged, see Triffin, 1968). This way free convertibility is a universal principle of confidence in money as it allows everyone, at any time, to realise the purchasing power of money. This is, in turn, related to the free transfer of property rights and a greater stability of private contracts.

\footnotetext{
${ }^{26}$ See for example Heilperin (1939).

${ }^{27}$ Ricardo strives to stabilise money only by means of reducing its volume, regardless of whether it is backed up or not.

${ }^{28}$ Laughlin (1931, vol. II, p.16) pointed out that: “ In other words, immediate redemption determines the quantity needed in circulation",
} 
The main source of confidence in a CB is close to that of GS - this is the principle of convertibility (with the two anchors mentioned - fixed rate and money coverage). It is the possibility to exchange a national currency at a legally fixed exchange rate into a 'strong' foreign currency, coupled with a commitment to back up totally a portion of money supply, e.g. monetary base (placing a natural limitation on the issuance of currency). It was not by chance that in Argentina the CB was known under the name of "convertibility system".

Another source of confidence under modern $\mathrm{CBs}$ could be considered the $C B$ supporting legislation and banking supervision (capital and liquidity requirements for banks, internal audit and organizational structure, etc.), which gives rise to much more stringent rules for the banking and financial activities and strengthens the confidence in the banking system ${ }^{29}$.

\section{Endogenous vs. exogenous confidence}

The confidence in the gold standard is a naturally generated confidence, which comes from the past of this monetary regime, from the long evolution of money as a means of exchange (Menger, 1892; Mises, 1912) ${ }^{30}$. It is a confidence, which stems from the decentralised activity of many generations of economic agents; it comes from "beneath" and is not externally enforced. It is a confidence arising from gold price stability in past periods (remember Mises' regression theorem, according to which the value of money may be logically derived from the value of commodity in the past periods). Sometimes, this stability is explained with the assertion that the annual flows of new gold are exclusively small compared to the stock of gold already amassed ${ }^{31}$.

\footnotetext{
${ }^{29}$ One another possible type of reasoning could be the following: If we look into the monetary rule (as both CB and GS are), we could in a way speak of a "chain of confidence", or of a whole string of interlinks in its generation. It could be stratified into several steps. First step - the sources of confidence of the public and individuals (as already mentioned). On second step we could ask about the grounds on which the confidence in the Central Bank (or its management) stands. Several sources could be pinpointed - confidence in the very functioning of CBs as an efficient mechanism, confidence in IMF (in the case of Bulgaria confidence in EU - that sooner or later we will join the Euro area and that we will not be left behind in a time of crisis) etc. Among the sources, as far as the Central Bank management is concerned, is the hope that the terms of office of its members will expire before an eventual crisis, or that they will be reappointed before the crisis, etc.

${ }^{30}$ That is, the issue of the initial stage of confidence does not stand here (it is always positive), as we will see is a major shortcoming of CBs.

${ }^{31}$ Under the bi-metallic standard it was relied on even greater stability of the price level as a result of the automatic rechannelling of money supply to the less costly material (as per Gresham's law). In this case the common trajectory of prices is determined by the cheaper material, so that the overall curve fluctuates within a smaller scope. (Laughlin, 1931). It is interesting to note that a similar idea was advanced by Oppers in his proposal of a dual CB (Oppers, 2000). See also Flandreau (1995).
} 
The confidence in the national currency under a $\mathrm{CB}$ arrangement derives from the confidence in the power of foreign fiat currency, the issuing bank and the area, in which it circulates. (The value of the Bulgarian lev becomes a function of the value of the Deutsche mark (Euro) $)^{32}$. That is, we could speak here of an imported confidence or of a delegated confidence from the standpoint of the country operating a CB. Within the context of imported confidence is the belief of economic agents (especially those in power) that International Financial Institutions (IMF in particular), as well as European Union, will be much more exacting from the monetary regimes, as well as possibly more benevolent in the event of crisis.

The first generation CBs were introduced after a period of a colonial CB, i.e., they inherit its reputation (that was the case with the British colonies, Uche, 1997). In this case confidence is derived from other countries' previous monetary practice and essentially from the image of a foreign monetary institution ${ }^{33}$. Second generation CBs (that is, modern CBs) emerge as a strategy for stabilisation after a crisis and disintegration of the old monetary system (a result of active and careless monetary policy) ${ }^{34}$. Such are the cases with CBs in Latin America and Eastern Europe. In the case of Lithuania and Estonia, CBs pegged initially to the dollar and the Deutsche mark are seen as a means of departure from the communist past (USSR and rouble zone) and joining the West. In this case, the initial level of confidence in the monetary regime is almost nil. Later on, economic agents convince themselves that the crisis is over and will not occur in the short run, i.e. confidence is generated not so much by past stability (past driven as in the case of orthodox $\mathrm{CBs}$ ), but rather by expectations for future stability (future driven). In some cases (Bulgaria, Estonia and Lithuania) the strategy to join Euro zone (which is optimistic exit strategy from CB), and all process of EU negotiations, could be considered as powerful sources of confidence at the monetary regime. Empirical proving of this hypothesis in the case of Bulgarian CB is down by Carson and Valev (2004).

\footnotetext{
${ }^{32}$ Under a CB arrangement exists the practice of currency substitution (formal or informal) whereby not only the reserve currency but also other strong currencies circulate along with the national currency, i.e., there is one additional corrective source (see Desquilbet and Nenovsky, 2003). The unofficial economy, which is in principle serviced by strong currencies, is also of definite significance.

${ }^{33}$ One of the main reasons to move to $\mathrm{CB}$, apart obtaining more monetary sovereignty, was the possibility to get segniorage.
} 
The resultant long-term stability has allowed temporary departures from GS (mainly in the time of war and/or in funding the costs of war), which were considered by economic actors as temporary deviations that could be easily recovered in the future (Bordo and Kydland, 1996) ${ }^{35}$. This is known as a contingent rule (rule with escape clause) or in McKinnon's terminology - a restoration rule. Unlike GS, it could be definitely argued that CBs do not allow any temporary departure from the monetary rule, or a subsequent return to it following McKinnon's restoration rule. This is so, because the accumulated confidence is very feeble and easily shaken (the Argentine crisis in 2001). That is, unlike GS, any disintegration of the CB rule is final and irreversible. This characteristic of CBs can be considered the other way round: the confidence in the arrangement depends on the announced or expected way out. In Bulgaria, for instance, there is a clear objective of joining the Euro-zone and the CB is seen as a preliminary stage. In Argentina, no agreement could be reached regarding official dollarization as a possible future of the monetary regime.

\section{International cooperation vs. unilateral decision}

In the third place, confidence in the gold regime stems also from the fact that it is an international (global) arrangement, that is, more or less simultaneously employed by the most developed countries. It was believed that belonging to the "gold standard club" is a symbol of prosperity and civilised life style and the way to be integrated into the world economy. For instance, similar were some of the reasons for introducing GS in Russia by Comte Sergey Witte in 1897 (Timoshina, 1998)). For instance Carl Menger (1936, vol. 4, pp. 154, 155) stressed: "It is no coincidence that the civilized nations are striving universally and urgently to introduce a gold currency. Gold is the money of advanced nations in the modern age.... Gold is the money of the world in our age; silver is the money of second-class countries only" It was not by chance that a restoration of the gold standard was attempted on so many occasions (for instance between the two world wars) when that was believed to be a symbol of a return to financial stability and

\footnotetext{
${ }^{34}$ The return to GS was also viewed as a strategy for overcoming a crisis, especially in the period between the two world wars.

${ }^{35}$ Although a logical question would be: How could it be expected to have the parity and convertibility restored at the prospect of a lost war, a substantial change in the price level?
} 
prosperity, as well as to an easy access to capital markets for the less developed countries (Bordo et al., 1999).

Analysing the credibility under the GS, we should to stress the lack of credibility in the peripheral countries, which was never overcome (e.g. Greece, Latin America). The raisons of this periphery's credibility deficit could be found in the lack of financial maturity (Bordo and Flandreau, 2001) or instable political institutions and powerful group interests, opposed to GS (Broz, 2002).

Modern CBs are very rarely independently introduced (Estonia and Hong Kong are exceptions). Normally, that happens under the pressure of IMF, foreign countries, or some foreign influential private groups (which interests were primary driven by foreign debt servicing) (see for details Nenovsky and Rizopoulos, 2003; Hanke, 2002, Blanc, 2003).

To summarise, there is a definite similarity between the two regimes, which is expressed in the fact that domestic currency is convertible into external anchor (gold or foreign fiat money) that is outside the national banking system. In spite of this and some other similarities, the confidence in the gold standard is a confidence generated by monetary evolution, e.g. from the past, or it is endogenously driven. Confidence in a CB environment comes primarily from the outside, or is exogenously driven, "forcibly created" and is focussed on a foreign monetary institution. With GS we observe a confidence from its own positive experience, while with CBs the confidence is derived from the experience of a foreign monetary practice (a result in a sense from its negative experience in discretionary managing monetary affairs). While convertibility with a pure GS is a subject outside any banking system, convertibility of domestic currency under a $\mathrm{CB}$ is into a foreign currency, which is itself domestically managed by another discretionary central bank.

We could also generalise that any change in the sources of confidence is a potential source of a crisis of that confidence. In other words, the stability of the monetary regime is changed; hence the likelihood for a crisis to emerge either increases or decreases.

The higher confidence and credibility of monetary institutions (such as GS and CBs), their ability to restore and maintain confidence, are seldom disputed. Normally, the focus of discussions, both historically and today (of course under different forms) is the existence and the 
forms of the automatic (or semi-automatic) adjustment mechanism under the two types of regimes. It is because in a sense, the existence of this mechanism is itself a source of confidence. Putting in others words, this attest the ability of the monetary regime to overcome shocks).

\section{How does adjustment take place?}

It is normally believed that the automatic adjustment is the second key factor, which determines the stability of a monetary regime (here some authors speak on discipline effect). Under GS and CBs the reliance is basically placed on this automatic mechanism (AM) ${ }^{36}$, on the a-personal management of money, on a kind of an invisible hand ${ }^{37}$, which overcomes economic shocks by means of adapting money supply to demand for money and balance of payments.

\section{Automatism}

A closer look at the economic literature, which to a different degree touches on the subject of money under a GS arrangement, reveals a clear trend of increasing doubt in AM efficiency, and even in its existence altogether ${ }^{38}$. This is especially pronounced during the period between the two world wars. The criticism against AM takes various forms (we will discuss them further below). Theoretical and empirical disputes about AM become central for understanding GS as its efficient operation is an alternative of the active discretionary central bank and no covered money. This is in contrast with the disputes on CBs where AM existence is only declared and hardly ever studied. Conceptually, however, the problem is the same. Suppose that $\mathrm{AM}$ does not exist. Then the question is: in the absence of active monetary discretion, how come that shocks are overcome?

AM definitions are not only numerous, but also of a different level of concreteness. The first theoretical step in defining AM is to be seen as a "black box", on two sides of which are the balance of payments and money supply. In this case we are not interested in what takes place inside the box. If we again refer to Meade (p. 189), AM is a rule, according to which "when a

\footnotetext{
${ }^{36}$ The term "AM" is borrowed from early physics and is deliberately aimed at eliminating a subjective interference in monetary affairs out and beyond the scope of the state.

${ }^{37}$ We do not know much about the invisible hand, nor do we know about AM.
} 
country has a deficit one thing or another will happen in order for money supply to decrease, and that means that the demand for goods and services will drop, the interest rate will go up (because cash will become scarce) until people decrease their demand on cash while money supply falls, too". And this is how Whale (1937) considers AM under GS: "the balance sheet imbalance, temporary at least, leads to an international gold movement: the movement of gold gives rise to changes in the volume of currency circulation in the affected country, shrinking here, expanding there: the changes in currency circulation lead to changes in incomes and prices, which balance the balance of trade".

The next analytical step is to look into details at the structure of AM, which is a system of links among certain variables along the "balance of payments - money supply" axis (see Ford, 1960; Meade, 1951; and the articles collected by Eichengreen and Flandreau, 1997). Building on the early analyses of Hume and Mills, AM involves movements in income and prices (general level or relative prices ${ }^{39}$ ), interest rates, the movement of capitals, loans, etc ${ }^{40}$.

AM under the different types of GS, as well as with the various GS configurations according to the countries participating in the international system, operates to a different degree of purity and in a different way (Meade, 1951; Nurkse, 1944). For instance, AM under a full gold standard arrangement operates in its purest form (this is so, because of the direct interlink between the balance of payments and monetary stock which coincided with a gold stock ${ }^{41}$ ). Over time (since the $19^{\text {th }}$ century), and with the shift to a fractional GS, as well as with the establishment of central bank monopoly, AM (i) becomes much more complex and (ii) requires "following the rules of the game" (Triffin, 1968; Plessis, 1998, pp.111-140). Triffin (1968) believes that "the automatic counterbalancing forces are augmented and accelerated by the central bank by means of the so called 'rules of the game'. It is their belief that the policy of

\footnotetext{
${ }^{38}$ See Bloomfield (1959) and Keynes (cited by Eichengreen, 1997, p. 121).

${ }^{39}$ The results are totally different when we consider adjustment via general price level, or via the structure of prices (there could be cases when the changes in the structure of price does not cause change in the price level). This especially was stressed by Hayek (see Heilperin, 1939).

${ }^{40}$ The possible empirical ways of testing AM are generally two: (i) testing the link between the two final points of the AM (balance of payments and money supply), or (ii) testing every causal chain within the AM. The good and detailed description of AM is given by Hawtrey (1932) and Meade (1951). Hawtrey especially stresses the role the central bank and the "rules of the game" for the AM. The crucial role of interest rate (respectively "rules of the games") as an integral part of the AM is underlined by the Cunliffe Report (1918). Macmillan Report (1931) also explicitly claimed that in order to protect the AM some central action is needed.

${ }^{41}$ This particularity of the pure GS is stressed by Hawtrey (1932, pp. $\left.174-179\right)$. See Flandreau (1995) for more details about GS functioning before 1870.
} 
discount interest rate and open market operations should raise interest rates and reduce lending in the countries with a deficit, whereas in the countries with a surplus it should reduce interest rates and increase lending". Interest rate increase should also lead to capital inflow, i.e. to making up for trade deficit. Thus, under the gold-fractional standard, in addition to changes through the movement of gold we also have changes through interest rates (e.g., elements of discretion). Practice has it that "the rules of the games" have not always been observed, even before 1914 in the area of classical GS (Bloomfield, 1959) ${ }^{42}$. For example, in the case of gold inflows, central banks did not lower interest rates, whereas they did raise interest rates in the case of gold outflows. Michaely (1971) stressed that "the loss of reserves is viewed with concern, but the accumulation ... is viewed with satisfaction or indifference".

Nevertheless, the system remains credible. Bordo and MacDonald (2003) argue that it is possible to preserve credibility without AM (the authors make a parallel with the theory of target zones in fixed exchange rates) ${ }^{43}$.

Similar is the definition of AM under a Currency Board. Perhaps the most comprehensive presentation of AM is made by Hanke and Schuler (1994), Hanke et al. (1993). A necessary condition for AM existence (similarly with GS) is supposed to be a long-term stability of the money preferences of economic actors (households, banks, etc.) ${ }^{44}$

As an example of adjustment under $\mathrm{CB}$, suppose the current account deficit as a result of a negative shock (either from domestic or external demand, or the trading environment...). This leads to reducing the banking system reserves, which in turn shrinks the extension of new loans, the majority of interest rates (on the interbank market, on loans and deposits) go up, ... and total income (consumption, investments) declines. Money demand also declines. Domestic prices decrease (or increase at a slower pace), which limits import demand. National currency becomes undervalued (the real exchange rate is depreciated), which improves the competitiveness of national goods, and ultimately leads to bridging the current account gap. Other channel, this of capital movement, exists in parallel: the higher interest rates attract capital, which adds to compensating the current account deficit. In this case there is no need to restore current account deficit, but rather to compensate it by capital account surplus. Using sterilization coefficients

\footnotetext{
42 The no respect of the AM functioning was empirically found for the interwar period by Nurkse (1944) and Simmons (1996). It was also analysed by the two reports: Cunliffe Report (1918) and Macmillan Report (1931).

${ }^{43}$ Keynes, too, stresses the importance of gold points for automaticism and confidence (Keynes, 1930).
} 
(the ration of y-o-y change in NDA to the y-o-y change in NFA) Hanke (2002) found that most of the Currency boards didn't follow the rule of non-sterilization (the coefficient of sterilization aren't zero). The weak presence (or even absence) of the AM Bulgaria, Estonia and Lithuania is econometrically found by Nenovsky and al. (2001).

Irrespective of the diversity of institutional forms within the framework of the two types of monetary regimes some of their specific features could be pointed out.

Asymmetry

In general, the further in time we get from the pure gold standard, the smaller the likelihood to come across an AM. The period of classical gold standard (1870 -1914) is perhaps the last period, where these elements of such a mechanism could be found. In effect, in order for $\mathrm{AM}$ to be quick and efficient, the monetary regime principles need to be one and the same world-wide or within the framework of a large group of countries, (which account for the greater part of world trade), e.g. to have an internationally operating monetary regime (formal and informal cooperation among countries need to exist $)^{45}$.

$\mathrm{CBs}$ do not meet this requirement for universality and internationality. It is difficult to imagine automatism in an individual country when the country of the reserve currency conducts active monetary policy. In that case, the system of interconnected reverse movement (symmetric arbitrage) of money supply, prices, etc. cannot be observed. Following this logic, with CBs we have an extreme asymmetric form of adjustment. Regardless of where the shock comes from, counterbalancing is only within the country operating the $\mathrm{CB}$ (since due to its size, the country to which we are pegged is not only insensitive to changes in the CB country, but does not take any commitment for synchrony either). A number of empirical studies of $\mathrm{CBs}$ evidence that there are strong reasons to doubt the functioning of AM, as it is not always the case of a long-term symmetric link between the balance of payments and monetary aggregates (Nenovsky and Hristov, 2002). This is partly due to the asymmetry, and partly to the existence of discretionary elements in almost all modern CBs (Nenovsky et al., 2001).

\footnotetext{
${ }^{44}$ For the importance of monetary behaviour under GS see Capie and Wood (1996); McCloskey and Zecher (1976).

${ }^{45}$ Let us remember the hardships of a single country in a GS context, trying to maintain full gold coverage while the rest are not doing it. The crucial role of central bank cooperation is stressed by Heilperin (1939).
} 
Still, we are talking about extreme asymmetry under CBs. However, we should remember that asymmetry as such has always existed in the GS between dominant countries (the core) and dominated countries (the periphery). It has been pointed out on quite a few occasions in the economic literature on GS, even for the period 1870-1914 (Nurkse, 1944, Ford, 1960, Triffin, 1968, Mouré, 1998). The countries then were under a hierarchy with Great Britain leading not only with respect to its colonies and undeveloped countries, but also to the other two major GS countries - the USA and France. Due to the special financial position of London, Great Britain was able to transfer the burdens of AM to the remaining peripheral and nonperipheral countries (by means of interest rate changes, which were noncompliant with the rules of the game).

Here, of special interest to us is Ford's analysis (1960), which shows that there is a fundamental difference between the adjustment of one central and one peripheral country (Great Britain and Argentina, respectively) ${ }^{46}$. What count also is the fact that the central country is a creditor, while the peripheral is a debtor (and usually a producer of raw materials). In this configuration "the creditor-country can always, and easier too, relieve its balance of payments by reducing its lending abroad; the debtor-country (the borrowing country) will face serious difficulties and even will not be able to borrow further...". A peripheral country with an active balance could possibly incur debt, and not gold. On the whole, the interest sensitivity of capital is weak. Ford, again, (1960) believes that crucial for AM is the countries' political structure, the existing lobbies, which block them, etc. ${ }^{47}$. With a peripheral country, even small changes in the balance of payments could bring about (internal) assault against the banking system (internal outflow of gold). The adjustment in a peripheral country is effected to a larger degree by changes in income and prices rather than through capital movement, lending and gold inflow.

The differences in GS AM manifestations at different countries are the focus of a number of recent studies. Bordo and Flandreau (2001) stress the difficulties of borrowing for peripheral countries (borrowing in central countries' money, gold clause), while Catao and Solomou (2003)

\footnotetext{
${ }^{46} \mathrm{Or}$, in other words, AM for some countries is more automatic compared to others, and is automatic in a different way. The role of special interest involved into the adjustment mechanism is stressed by De Cecco (1974), Frieden (1992) and Eichengreen (1997). De Cecco's book is maybe the first book deeply exploited the idea that every monetary order is result of fight and cooperation between different groups of interest (international and national) ${ }^{47}$ Officer (1996, p. 255) believes that the efficiency of a monetary regime is measured by the extent, to which it creates conditions for players' behaviour in favour of preserving AM.
} 
point out that the peripheral countries are balanced by means of the real effective exchange rate (as a result of changes in the nominal exchange rate), thus preserving GS in central countries.

What was mentioned about the asymmetry in a GS environment is even more pronounced under modern $\mathrm{CB}$ arrangements. However, the question raised here is, assuming that there is a natural and genetic asymmetry between monetary arrangements around the world, could the alternative regimes of CBs (thinking of discretionary central banks and floating exchange rates) do better as regards the difficulties of adjustment?

\section{Financial environment.}

When comparing CBs with the GS classical period 1870 - 1914 (and even to a greater extent in the period between the two world wars), it could be noticed at first glance that CBs lack completely (or almost completely) the possibility of employing interest rates in open market operations by monetary authorities. Whereas with GS they were relatively regularly used (depending on the period and the country, see "the rules of the game"), with most CBs this is not possible, due to the fact that the $\mathrm{CB}$ balance sheet does not include national securities. In this respect, comparing to the GS, $\mathrm{CB}$ could be considered as even more static regime. Of course, under some CBs this rule was not complied with (e.g. Argentina in the late 1990s), while with others the monetary authorities actively intervened in times of crises (e.g. Hong Kong 1997$1998)^{48}$.

Further on, when AM is analysed under two regimes, we should bear in mind the important to stress the economic and financial development since the period of GS, the propagation of different financial and monetary innovations, the growth of banking intermediation and the globalization of financial flows. This is clearly evidenced when we observe the two extreme "poles" of AM - money stock and balance of payments ${ }^{49}$. The share of deposits and other monetary substitutes gradually increased within the money supply, while the

\footnotetext{
${ }^{48}$ However, according to Steve Hanke, in almost all CBs there are processes of monetary sterilisation, which the author considers a glaring discrepancy with the CB principles (Hanke, 2002). Besides, most modern CBs maintain foreign reserves in excess of their monetary base, which leads to deviations in the operation of the automatic mechanism. It is possible to establish here conflicting elements between automaticism and credibility. Because the over coverage implies higher credibility, however obstructs the automatic mechanism.

${ }^{49}$ In the time of GS the balance of payments almost coincided with trade balance, and monetary stock with gold stock (Heilperin, 1939, p. 23).
} 
importance of banknotes and coins is decreasing nowadays. This places greater importance on the banking system (on money multiplier) in the AM transmission under CB. An issue that is immediately raised here is the need to include the familiar set of problems associated with the asymmetry of information in the banking sector (credit rationing) as a major part of AM (which has not been done so far). As to the balance of payments, its structure is also evolving, the relative importance of capital movements is increasing at the expense of trade. This once again and more pressingly brings forward the issue of AM asymmetry whereby peripheral countries' capital outflows do not return to the original source (symmetry is destroyed). Besides, the flight of capital today, compared to the time of GS, is considerably higher. Thus, while becoming more complex, AM becomes more vulnerable, too.

\section{Box: Price level determination under the GS and CB}

If we extend Kydland and Wynne (2002) presentation of the GS, we could present the GS and CB price level determination as follow. First assume that the supply of money $M^{S}$ is given by: $M^{S}=\frac{1}{\lambda} e F$, where $0<\lambda \leq 1$ is the degree of coverage of the inside money by outside money, $e$ is the nominal price at which the monetary authority stands willing to buy and sell the outside money, $F$ is the stock of outside money which evolves according to the difference between exportations $X$ and importations IMP: $\triangle F=X-I M P$. The demand for money is given by: $M^{D}=f\left(\pi^{e}, z\right) P y$, where $\pi^{e}$ is expected inflation, $z$ is a vector of other variables determined demand for money, $P$ is general price level and $y$ is real income.

If we suppose money market equilibrium $\left(M^{D}=M^{S}\right)$ we can obtain the price level under GS as:

$$
P=\frac{e F}{\lambda f\left(\pi^{e}, z\right) y}=\frac{e \sum(X-I M P)}{\lambda f\left(\pi^{e}, z\right) y}
$$

Under the CB (especially second generation) there are some important structural changes: (i) the coverage exist only for the base money, not the all monetary stock (ii) with the development of the bank money, nowadays the monetary stock is far bigger that the money in circulation (this stresses the role of the banking system and the role of money multiplayer), (iii) nowadays the capital account presents an important part of the balance of payments, when in the previous time the balance of payment was closer to the trade account. Let $M^{S}=\mu H$, where $H$ is monetary base, and $\mu$ is the money multiplayer, assume that only $\mathrm{H}$ is covered by $\mathrm{F}$. Taking into account the role of capital flows in the determination of the stock of outside money, let $\Delta F=X-I M P+\Delta K$, where $\Delta K$ represents net capital flows. We obtain the price level under CB:

$$
P=\frac{\mu e \sum(X-I M P+\Delta K)}{\lambda f\left(\pi^{e}, z\right) y}
$$

Comparing (1) and (2) it is obvious that the price level determination is much more instable under CB because of the two behavioral variables such as money multiplayer $\mu$ and net capital flows $\Delta K$. 


\section{Conclusion - some lessons from the gold standard for CB}

What has been said so far helps us to arrive at several conclusions, or rather to formulate hypotheses, which would be a subject for further investigation.

First, there is a great diversity within the framework of GS and CB, which makes their comparison difficult. In order to define these two types of monetary regimes a number of simplifications (often subjective) need to be made. The evolution of balance of payments and money stock should be taken into account. The monetary assets are much more diversified and the capital movements much more important.

Second, we should make a clear-cut distinction between confidence and credibility, on the one hand, (confidence effect), and automatic mechanism, on the other (discipline effect). The effect of confidence is the major advantage of the two regimes. The automatic mechanism is in itself disputable: theoretically not completely consistent and empirically unproved. It could be asserted with certain conditionality that AM is more appropriate of the full-fledged GS, however, with time it becomes more and more asymmetric (form the point of view the periphery) and problematic as a whole.

Third, the permanent and direct convertibility of a national currency into an object of stable purchasing power (which is outside the national banking system) is the main source of confidence and credibility. The fixed exchange rate and the all-time coverage of money supply (or some narrow monetary aggregate) are basic for the confidence in money. Both regimes are efficient means of financial stabilisation after a period of war or crisis. While the confidence in money under GS comes from the thousands of years of practice of the population, the confidence under CBs is rather brought from the outside: it is a confidence in a foreign monetary institution (of economically developed country). In the case of CB in accession countries (Bulgaria, Estonia and Lithuania) the confidence is generated mainly from future EU perspectives and adoption of the euro (entering into the large monetary area).

Fourth, as a whole, CBs are enforced (or deliberately created, generally by outside forces), while GS has emerged spontaneously (although at a later stage the state is constantly interfering in its operation). 
Fifth, in spite of the assertions that are often made, both regimes contain elements of discretion. Both regimes are asymmetric (a centre and a periphery could be discerned). This asymmetry is much more pronounced under CBs. We could even go further and say that CB is a "hypertrophied" asymmetric arrangement. A typical element of asymmetry is the fact that adjustment is primarily achieved at the expense of the pegged countries, and not of the central ones. This does not mean that we "judge" this asymmetry as unacceptable; we simply state it as a fact $^{50}$.

Sixth, we could assume that on the whole confidence and credibility make up for the difficulties of functioning of AM. The resistance to crisis under the two types of regimes depends on the overall behaviour of economic players and the government above all. When the latter follows a prudent financial policy and the country is not involved in a war, these regimes are greatly efficient.

Nevertheless, for the moment we cannot but support the assertion about the nonexistence of ideal monetary regimes, non-existence of pure monetary forms.

\footnotetext{
${ }^{50}$ It is partly because every monetary regime should be compared with the alternatives monetary regimes, and partly with the fact the fact that its efficacy could be checked only contrafactually).
} 


\section{Bibliography}

Aftalion, A. (1938), L'or et la monnaie. Leur valeur. Les mouvements de l'or., Les éditions Domat-Montchrestien, Paris.

Bernholz, P. (2003), Monetary Regimes and Inflation. History, Economic and Political Relationships, Edward Elgar, Cheltenham.

Bernholz, P. (2001), "Monetary Constitution, Political-Economic Regime and Long-Term Inflation", Constitutional Political Economy, vol. 12, pp. 3-12.

Blanc, J., JF. Ponsot (2003), Crédibilité et Currency board: le cas lithuanien, mimeo.

Blanc, J. (2003), Les conditions d'établissement d'un Currency board: l'exemple lithuanien, 1990-1994, mimeo.

Blanc, J. (2000), Les monnaies parallèles. Unité et diversité du fait monétaire, L'Harmattan, Paris.

Bordo, M. (2003), The inter-war gold exchange standard: credibility and monetary independence. Journal of International Money and Finance 22, 1-32

Bordo, M. (2002), Monetary Standards, http://econweb.rutgers.edu/bordo/encyclopedia.doc

Bordo M. (2002), Exchange Rate Regime Choice in Historical Perspective, IMF WP/03/160

Bordo M., M. Edelstein, H. Rockoff (1999), Was Adherence to the Gold Standard a "Good Housekeeping Seal of Approval” During the Interwar Period?, NBER WP 7186.

Bordo, M., F. Kydland (1996), The gold standard as a commitment mechanism, in Bayoumi, T., B. Eichengreen, M. Taylor, Eds.: Modern perspectives on the gold standard, Cambridge University Press.

Bordo, M., M. Flaundreau (2001), Core, Periphery, Exchange Rate Regimes, and Globalization, in Michael D. Bordo, Alan M. Taylor and Jeffrey G. Williamson, Editors, Globalization in Historical Perspective, NBER Conference held May 4-5, 2001, Forthcoming from The University of Chicago Press

Broz, J. (2002), The Political Economy of Commitment to the Gold Standard, Paper for Annual Meeting of the American Political Sciences Association, August 29 - September 1, 2002.

Camillieri Gilson, M-T. (2002), Policy pre-commitment and institutional design: a synthetic indicator applied to Currency Boards, OECD working paper N 16.

Capie, F., G. Wood (1996), Money demand and supply under the gold standard: the United Kingdom, 1870-1914, in Bayoumi, T., B. Eichengreen, M. Taylor, Eds.: Modern Perspectives on the gold standard, Cambridge University Press, p 261-283

Carlson, J., N. Valev (2001), "Credibility of a new monetary regime: the currency board in Bulgaria”, Journal of Monetary Economics, vol. 47, pp. 581-594.

Carlson, J., N. Valev (2004), "Beliefs about Exchange-Rate Stability in a Transition Economy: Evidence from the Currency Board in Bulgaria”, mimeo. 
Carré, E. and E. le Heron (2004). ***

Catao L., S. Solomou (2003), Exchange Rates in the Periphery and International Adjustment Under the Gold Standard, IMF Working paper/03/41

Combes, J., R. Veyrune (2003), Direct and side effects of nominal fixity, CERDI, University of Auvergne, mimeo.

Cowen, T., A. Glazer, K. Zajc (2000), Credibility may require discretion, not rules, Journal of Public Economics, vol. 76, pp. 295-306.

Cunliffe Committee on Currency and Foreign Exchanges after the War, in: Eichengreen, B., M. Flandreau Eds., (1997), The gold standard in theory and history, Routledge, London and New York.

De Cecco, M. (1974), Money and Empire, Basil Blackwell

Della Paolera, G., A.Taylor (2002), Internal versus external convertibility and emerging-marker crises: lesson from Argentine History, Explorations in Economic History, vol. 39, pp. 357389.

De Grauwe, P. (1996), International Money, Oxford University Press

De Soto, H. (2001). The Mystery of Capital. Why capitalism triumphs in the West and fails everywhere else, Black Swan Editions.

Desquilbet, J-B. and N. Nenovsky (2003), Exploring the Currency board mechanics'. A basic formal model, Bulgarian National Bank Discussion papers, No 35.

Eichengreen, B. and M. Flandreau (1997), Editors' introduction, in: Eichengreen, B., M. Flandreau Eds., (1997), The gold standard in theory and history, Routledge, London and New York.

Eichengreen, B. (1997). L'expansion du capital. Une histoire du système monétaire international, L' Harmattan.

Fisher, I. (1920), Stabilizing the Dollar. A plan to stabilize the general price level without fixing individual prices, The MacMillan Company, New York.

Flandreau, M. (1995), L'or du monde. La France et la stabilité du system monétaire international 1848-1873, Editions L'Harmattan, Paris

Ford, A. (1960), Notes on the working of the gold standard before 1914, in Eichengreen, B., M. Flandreau Eds., (1997), The gold standard in theory and history, Routledge, London and New York.

Frieden, J. (1992). The dynamics of international monetary systems: international and domestic factors on the rise, reign, and demise of the classical gold standard, in Eichengreen, B., M. Flandreau Eds., (1997), The gold standard in theory and history, Routledge, London and New York.

Ganev, G. (2003). The level of confidence in the exchange rate regime in Bulgaria (1991 - 2003) - essay in calibration, Bulgarian National Bank Discussion papers, No 38.

Garisson, R. (1985), The "Costs" of a Gold Standard, in: Llewellyn H. Rokwell, Jr, Ed., The Gold Standard: An Austrian Perspective, Lexington, MA, pp. 61-79. 
Gilpin, R. (2001), Global political economy. Understanding the international economic order, Princeton and Oxford, Princeton University Press.

Hanke (2002), On Dollarization and Currency Boards: Error and Deception, Policy Reform, 2002, Vol. 5(4), pp. 203-222

Hanke, S. (2003), The Argentine Straw Man: A response to Currency Boards Critics, Cato Journal, vol. 23, No 1,

Hanke, S. and K. Schuler (1994), Currency Boards for Developing Countries: A Handbook (An International Center for Economic Growth Publications), ICS Press, San Francisco, California

Hanke, S. H., Jonung, L. and Schuler. K. (1993), Russian Currency and Finance. London: Routledge.

Hanke, S. (2002), On Dollarization and Currency Boards: Error and Deception, Policy Reform, vol. 5, no 4, pp.203-222.

Hawtrey, R. (1932). The Art of Central Banking, Longmans, Green and Co., London.

Heilperin, M. (1939), Equilibrium in International Payments, in Heilperin, M. (1968), Aspects of the pathology of Money. Monetary Essays from Four Decades, Michael Joseph Limited, Geneva.

Higgs, R. (1997). Regime Uncertainty: Why the Great Depression Lasted So Long and Why Prosperity Resumed after the War, The Independent Review, vol.1, No 4, Spring, pp. 561590.

Ho, C. (2001), Contemplating the Credibility of the Currency Boards, Doctoral Dissertation, Department of Economics, Princeton University.

Kébabdjian, G. (1999), Les théories de l'économie politique internationale, Paris, Editions de Seuil.

Keynes, J.M. (1930), A Treatise on Money. New York: Harcourt Brace.

Knafo, S. (2003), The gold standard and the origins of the modern International monetary system, Cahiers de Recherche - CEIM, Université du Québec à Montréal, http://www.ceim.uqam.ca

Kydland, F. and M. Wynne (2002), Alternative Monetary Constitutions and the Quest for Price Stability, Federal Reserve Bank of Dallas Economic and Financial Policy Review, vol. 1, N 1.

Laughlin, J.L. (1931), A New Exposition of Money, Credit and Prices, Vol. I The Evolution of the Standard and Vol. II The Economics of Credit and Prices, The University of Chicago Press, Chicago, Illinois.

Lelart, M. (1977), De l'étalon-or aux balances sterling, Revue Banque, N 367, pp. 1185-1191, and N 368, pp. 1289-1297.

Lewis, M. K. (2002). Currency Boards and Currency Arrangements in Transition economies, in: Sevic, Z., ed., (2002), Banking Reforms in South-East Europe, Edward Elgar. 
Macmillan Committee on Finance and Industry (1918), in: Eichengreen, B., M. Flandreau Eds., (1997), The gold standard in theory and history, Routledge, London and New York.

McCloskey, D., J. Zecher (1976), How the gold standard worked, 1880-1913, in: Eichengreen, B., M. Flandreau Eds., (1997), The gold standard in theory and history, Routledge, London and New York.

McKinnon, R. (1993), The Rules of the Game: International Money in Historical Perspective, Journal of Economic Literature, vol. XXXI (March), pp. 1-44.

Meade, J. (1951), The Balance of Payments. The Theory of International Economic Policy, vol.1 Oxford University Press

Menger, C. (1892), On the Origins of Money, Economic Journal, volume 2, p. 239-255.

Menger, C. (1936), The Collected Works of Carl Menger, London Scool of Economics and Political Sciences, vol. 4

Michaely, M. (1971), The responsiveness of demand policies to balance of payments, New York, Oxford University Press.

Mises, L. (1912), The Theory of Money and Credit, Jonathan Cape, London, 1934.

Mouré, K. (1998), La politique du Franc Poincaré (1926-1936), Paris, Albin Michel.

Niehans, J. (1978), The Theory of Money, The Johns Hopkins University Press, Baltimore and London.

Nogaro, B. (1924), La monnaie et les phénomènes monétaires contemporains, Marcel Giard, Editeur, Paris.

Nenovsky, N., K. Hristov and M. Mihaylov (2001), Comparing Currency Board Automatic Mechanism in Bulgaria, Estonia and Lithuania, Journal des Economistes et des Etudes Humaines, vol. XI, n 4, pp. 575 - 616.

Nenovsky, N., K. Hristov (2002), "New Currency Boards and discretion. The empirical evidence from Bulgaria", Economic Systems, March, vol.26. n 1, pp. 55-72.

Nenovsky, N., Y. Rizopoulos (2004), Peut-on mesurer le changement institutionnel du régime monétaire ?, Revue d'économie financière, vol. 75, 2004, forthcoming.

Nenovsky, N., Y. Rizopoulos (2003), Extreme Monetary Regime Change. Evidence from Currency Board Introduction in Bulgaria, Journal of Economic Issues, vol. XXXVII, N4, December, pp. $909-941$

Nurske, R. (1944), International Currency Experiences. Geneva League of Nations.

Officer, L. (1996), Between the dollar-sterling gold points: Exchange rates, party and market behavior. Cambridge University Press p. 255-266

Oppers, S. (2000), Dual Currency Boards: A Proposal for Currency Stability, IMF Working Paper WP/00/199.

Plessis, A. (1998), Histoires de la Banque de France, Bibliothèque Alban Michel Histoire, Paris.

Poole W. (2003), Institutions for Stable Prices: How To Design an Optimal Central Bank Law, Review (Federal Reserve Bank of Saint Louis), Sep/Oct 2003, Vol. 85 Issue 5, p1-5 
Rist, Ch. (1938), Histoire des doctrines relatives au crédit et a la monnaie (depuis John Low jusqu'a nos jours), Dalloz, Paris, 2002.

Rueff, J. (1927), Théorie des phénomènes monétaires, Payot, Paris.

Sargent, T. (1982), The Ends of Four Big Inflations, in Robert E. Hall ed., Inflation: Causes and Effects, pp. 41-97, University of Chicago Press

Schuler, K. (1992), Currency Board;, Ph.D. Thesis, Fairfax: George Mason University.

Simmons, B. (1996). Rulers of the game: central bank independence during the interwar years, International Organization, vol. 50, No 3, Summer, pp. 407 - 443.

Timoshina, T. (2003), Economic History of Russia. Editions Usticinform, Moscow (in Russian),

Triffin, R. (1968), Gold and the Dollar Crisis. New Haven: Yale University Press,

Tsang S-K (1999), Fixing the exchange rate through a currency board arrangement: efficiency risk, systemic risk and exit cost, Asian Economic Journal, vol. 13 n³, pp. 239-266

Walsh, C. (1998), Monetary Theory and Policy, The MIT Press, Cambridge.

Whale, P. (1937), The working of the prewar gold standard, in: Eichengreen, B., M. Flandreau Eds., (1997), The gold standard in theory and history, Routledge, London and New York.

Yeager, L. (2001), The Perils of Base Money, The Review of Austrian Economics, vol. 14, no 4, pp. 251-266.

Uche, C. (1997), Bank of England vs the IBRD: Did the Nigerian Colony Deserve a Central bank?, Explorations in Economic History, vol.34, pp. 220-241. 


\section{DAVIDSON INSTITUTE WORKING PAPER SERIES - Most Recent Papers}

The entire Working Paper Series may be downloaded free of charge at: www.wdi.bus.umich.edu

CURRENT AS OF $10 / 01 / 2004$

\begin{tabular}{|c|c|c|}
\hline Publication & Authors & Date \\
\hline No. 722: Russia from Bust to Boom: Oil, Politics or the Ruble? & $\begin{array}{l}\text { Bruno Merlevede and Koen } \\
\text { Schoors }\end{array}$ & Oct. 2004 \\
\hline No. 721: Distance to the Efficiency Frontier and FDI Spillovers & $\begin{array}{l}\text { Klara Sabirianova Peter, Jan } \\
\text { Svejnar, and Katherine Terrell }\end{array}$ & Sept. 2004 \\
\hline $\begin{array}{l}\text { No. 720: An Analysis of Gender Wage Differentials in Russia from } \\
\text { 1996-2002 }\end{array}$ & Rita Hansberry & Sept. 2004 \\
\hline $\begin{array}{l}\text { No. 719: Returns to Schooling in Russia and Ukraine: } \\
\text { A Semiparametric Approach to Cross-Country Comparative Analysis }\end{array}$ & $\begin{array}{l}\text { Klara Sabirianova Peter and } \\
\text { Yuriy Gorodnichenko } \\
\end{array}$ & Sept 2004 \\
\hline $\begin{array}{l}\text { No. 718: The emergence of large shareholders in mass privatized } \\
\text { firms: Evidence from Poland and the Czech Republic }\end{array}$ & Irena Grosfeld and Iraj Hashi & Aug. 2004 \\
\hline $\begin{array}{l}\text { No. 717: Wage Determination Under Communism and In Transition: } \\
\text { Evidence from Central Europe }\end{array}$ & $\begin{array}{l}\text { Swati Basu, Saul Estrin and Jan } \\
\text { Svejnar }\end{array}$ & Aug. 2004 \\
\hline No. 716: The Evolution of Cross-Region Price Distribution in Russia & Konstantin Gluschenko & July 2004 \\
\hline $\begin{array}{l}\text { No. 715: Languages in the European Union: The Quest for Equality and } \\
\text { its Cost }\end{array}$ & $\begin{array}{l}\text { Jan Fidrmuc and Victor } \\
\text { Ginsburgh }\end{array}$ & July 2004 \\
\hline $\begin{array}{l}\text { No. 714: Voice of the Diaspora: An Analysis of Migrant Voting } \\
\text { Behavior }\end{array}$ & Jan Fidrmuc and Orla Doyle & July 2004 \\
\hline $\begin{array}{l}\text { No. 713: International Coercion, Emulation and Policy Diffusion: } \\
\text { Market-Oriented Infrastructure Reforms, } 1977-1999\end{array}$ & $\begin{array}{l}\text { nd Bennet A. } \\
\text { F. Guillen }\end{array}$ & July 2004 \\
\hline $\begin{array}{l}\text { No. 712: Votes and Vetoes: The Political Determinants of Commercial } \\
\text { Openness }\end{array}$ & $\begin{array}{l}\text { Witold J. Henisz and Edward D. } \\
\text { Mansfield }\end{array}$ & July 2004 \\
\hline $\begin{array}{l}\text { No. 711: Interest Groups, Veto Points and Electricity Infrastructure } \\
\text { Deployment }\end{array}$ & $\begin{array}{l}\text { Witold J. Henisz and Bennet A. } \\
\text { Zelner }\end{array}$ & July 2004 \\
\hline $\begin{array}{l}\text { No. 710: Firms' Price Markups and Returns to Scale in Imperfect } \\
\text { Markets: Bulgaria and Hungary }\end{array}$ & $\begin{array}{l}\text { Rumen Dobrinsky, Gábor Körösi, } \\
\text { Nikolay Markov, and László } \\
\text { Halpern }\end{array}$ & July 2004 \\
\hline 每 & Gábor Orbán and György Szapáry & July 2004 \\
\hline $\begin{array}{l}\text { No. 708: Contract Violations, Neighborhood Effects, and Wage Arrears } \\
\text { in Russia }\end{array}$ & Klara & July 2004 \\
\hline $\begin{array}{l}\text { No. 707: Determinants of Employment Growth at MNEs: Evidence } \\
\text { from Egypt, India, South Africa and Vietnam }\end{array}$ & $\begin{array}{l}\text { laumik, Saul } \\
\text { Meyer }\end{array}$ & July 2004 \\
\hline $\begin{array}{l}\text { No. 706: Economic Reform in Tanzania and Vietnam: A Comparative } \\
\text { Commentary }\end{array}$ & $\begin{array}{l}\text { Brian Van Arkadie and Do Duc } \\
\text { Dinh }\end{array}$ & June 2004 \\
\hline $\begin{array}{l}\text { No. 705: Beliefs about Exchange-Rate Stability: Survey Evidence } \\
\text { from the Currency Board in Bulgaria }\end{array}$ & $\begin{array}{l}\text { Neven T. Valev and John A. } \\
\text { Carlson }\end{array}$ & June 2004 \\
\hline No. 704: Returns to Schooling in China Under Planning and Reform & $\begin{array}{l}\text { Belton M. Fleisher and Xiaojun } \\
\text { Wang }\end{array}$ & June 2004 \\
\hline $\begin{array}{l}\text { No. 703: Return to Skills and the Speed of Reforms: Evidence from } \\
\text { Central and Eastern Europe, China and Russia }\end{array}$ & \begin{tabular}{|l} 
Belton M. Fleisher, Klara \\
Sabirianova Peter, and Xiaojun \\
Wang \\
\end{tabular} & June 2004 \\
\hline $\begin{array}{l}\text { No. 702: What Makes Small Firms Grow? Finance, Human Capital, } \\
\text { Technical Assistance, and the Business Environment in Romania }\end{array}$ & $\begin{array}{l}\text { J. David Brown, John S. Earle } \\
\text { and Dana Lup }\end{array}$ & May 2004 \\
\hline $\begin{array}{l}\text { No. 701: The Effects of Multiple Minimum Wages Throughout the } \\
\text { Labor Market }\end{array}$ & $\begin{array}{l}\text { T. H. Gindling and Katherine } \\
\text { Terrell }\end{array}$ & May 2004 \\
\hline No. 700: Minimum Wages, Inequality and Globalization & $\begin{array}{l}\text { T. H. Gindling and Katherine } \\
\text { Terrell }\end{array}$ & May 2004 \\
\hline No. 699: Self-Selection and Earnings During Volatile Transition & Ralitza Dimova and Ira Gang & May 2004 \\
\hline No. 698: Ecology and Violence: The Environmental Dimensions of War & $\begin{array}{l}\text { Timothy L. Fort and Cindy A. } \\
\text { Schipani } \\
\end{array}$ & May 2004 \\
\hline $\begin{array}{l}\text { No. 697: Russian Cities in Tran } \\
\text { the 1990s }\end{array}$ & Ira N. Gang and Robert C. Stuart & May 2004 \\
\hline
\end{tabular}

